\title{
Population identification of common cuttlefish (Sepia officinalis) inferred from genetic, morphometric and cuttlebone chemistry data in the NE Mediterranean Sea
}

\author{
CEMAL TURAN and DENIZ YAGLIOGLU \\ Fisheries Genetics Laboratory, Department of Basic Sciences, Faculty of Fisheries, Mustafa Kemal University, \\ 31200 Iskenderun, Hatay, Turkey. E-mail: cturan@ymail.com
}

SUMMARY: The population structures of the common cuttlefish Sepia officinalis from the north-eastern Mediterranean (Antalya and Iskenderun Bays), Aegean (Izmir Bay) and Marmara Seas were analyzed with mtDNA PCR-RFLP, body morphometry and cuttlebone chemistry. Analysis of a ND 5/6 (Nikotin Amid Adenin Dehidrojenaz-5/6) gene segment of mtDNA revealed seven haplotypes from 120 individuals. No haplotype sharing was observed among sampling sites. The average nucleotide divergence between samples was 0.009390 , and the highest genetic divergence $(0.015279)$ was observed between the Iskenderun Bay and Marmara Sea samples. The lowest genetic divergence $(0.003786)$ was between the Aegean Sea and Antalya Bay samples. Highly significant differences $(P<0.001)$ between all sampling sites were observed in both the Monte Carlo and AMOVA analyses. In the UPGM tree, the neighbouring Antalya and Aegean samples clustered as the closest clades, and the most isolated Marmara and Iskenderun Bay samples clustered as the most divergent clades. In discriminant function analysis, the classification success rates in assigning fishes to the correct region of origin were 66 and $100 \%$ for morphometry and cuttlebone chemistry respectively. In the morphometric analysis, only the Marmara Sea and Iskenderun Bay samples were differentiated from each other, and the rest of the samples overlapped each other. In cuttlebone chemistry analysis, univariate statistics revealed highly significant $(P<0.001)$ differences among locations for 12 elements: $\mathrm{Al}, \mathrm{Ca}, \mathrm{Cd}$, $\mathrm{Cr}, \mathrm{Cu}, \mathrm{Fe}, \mathrm{K}, \mathrm{Mg}, \mathrm{Mn}, \mathrm{Na}, \mathrm{Pb}, \mathrm{Zn}$. In multivariate analysis, highly significant differences $(P<0.001)$ were observed between the four locations. This study showed that there are four discrete populations of $S$. officinalis in Turkish coastal waters.

Keywords: Sepia officinalis, population identification, genetic, morphometry, cuttlebone chemistry.

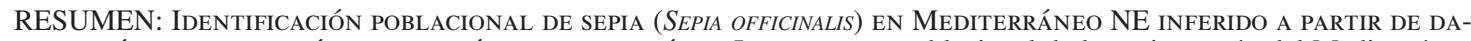
TOS GENÉTICOS, MORFOMÉTRICOS Y QUÍMICOS DEL SEPIÓN. - La estructura poblacional de la sepia común del Mediterráneo noreste (bahías de Antalya y de Iskenderun), Mar Egeo (Bahía de Izmir) y Mar de Mármara ha sido analizada mediante la técnica de PCR-RFLP del ADN mitocondrial (mtDNA), la morfometría del cuerpo y química del sepión. El análisis de variabilidad de secuencia de un fragmento del gen mitocondrial ND 5/6 (Nikotin Amid Adenin Dehidrojenaz-5/6) de 120 individuos reveló siete haplotipos distintos. Ninguno de ellos compartido entre localidades. La divergencia nucleotídica media entre muestras es de 0.009390 , con el máximo valor de divergencia genética $(0.015279)$ observado entre las localidades de la bahía Iskenderun y el Mar de Mármara, y el mínimo valor de divergencia genética (0.003786) entre las localidades del mar Egeo y la bahía de Antalya. Los análisis basados en las simulaciones de Monte Carlo y AMOVA mostraron diferencias altamente significativas $(P<0.001)$ entre todas las localidades. En el árbol filogenético de UPGMA, las localidades colindantes de Antalya y de Mar Egeo se agrupan en la misma rama. Por otro lado, las localidades más aisladas, Mar de Mármara y bahía de Iskenderun, se distribuyen en los clados más divergentes. En el análisis de la función discriminante, la clasificación de las tasas de éxito en la asignación de especímenes a las regiones fue $66 \%$ para el análisis morfométrico y un $100 \%$ para la química del sepión. En el análisis morfométrico solamente se detectaron diferencias significativas entre las muestras del Mar de Mármara y la bahía de Iskenderun, mientras que el resto de localidades se agrupan entre ellas. En el análisis de la química del sepión, el análisis univariante ha revelado diferencias altamente significativas $(P<0.001)$ entre todas las regiones en 12 elementos $\mathrm{Al}, \mathrm{Ca}, \mathrm{Cd}, \mathrm{Cr}, \mathrm{Cu}, \mathrm{Fe}, \mathrm{K}, \mathrm{Mg}, \mathrm{Mn}, \mathrm{Na}, \mathrm{Pb}, \mathrm{Zn}$. En el análisis multivariante se observan diferencias altamente significativas $(P<0.001)$ entre las cuatro localidades. Este estudio muestra la presencia de cuatro poblaciones separadas de $S$. officinalis a lo largo de las aguas de la costa turca.

Palabras clave: Sepia officinalis, identificación poblacional, genética, morfometría, química del sepión. 


\section{INTRODUCTION}

Reliable management of fish populations should be based on truthful biological data for sustainable exploitation of biological marine resources (Carvalho and Hauser, 1994). In marine species, demographic processes and fishery activities can vary considerably between populations or stocks. The potential capacity of populations to adapt and evolve as independent biological entities in different environmental conditions depends on the exchange of individuals between populations. Restricted exchange may lead to self-recruiting units, which have divergent genotypes, chemical structures and morphology (Carvalho and Hauser, 1994; Turan et al., 2006; Volpedo and Cirelli, 2006). Identification of intraspecific groups of marine fish species with different genetic and morphological characteristics is essential for understanding population dynamics and estimating sustainable harvests (Carvalho and Hauser, 1994).

The common cuttlefish (Sepia officinalis L. 1758) is a demersal and neritic species occurring predominantly on sandy to muddy bottoms from the coastline to about $200 \mathrm{~m}$ depth (FAO, 2003), and has a high commercial value in European countries (Perrin et $a l ., 2004)$. It is distributed along the NE Atlantic, from the Baltic Sea to Senegal, and throughout the Mediterranean, Aegean and Marmara Seas (Guerra, 1992). S. officinalis is the most widely-known species of cuttlefish in Turkey. The contribution of $S$. officinalis to local fisheries differs in each sea: $9 \%$ of the total fish catch in the Aegean Sea (Salman et $a l ., 1997)$ and 5-6\% in the Mediterranean Sea (Salman and Katağan, 2004). There has been a number of stock structure analyses of $S$. officinalis carried out in European waters which report biology, morphology and genetic differences between populations (Shaw et al., 1999; Perez-Losada et al., 1999; Perez-Losada et al., 2002; Wolfram et al., 2006). However, in Turkish waters there is only information on the biology and distribution of S. officinalis (Duysak et al., 2004; Salman and Katağan, 2004). There is no information on the population structure of S. officinalis in the fishing grounds of the northeastern Mediterranean, Aegean or Marmara Seas.

Studies on mtDNA using restriction fragment length polymorphism (RFLP) analysis have shown it to be a powerful genetic marker for assessing genetic variation among populations (Hauser et al., 2001; Turan et al., 2009). Maternal inheritance and the absence of recombination make mitochondrial DNA an appropriate tool for reconstructing the recent history of populations (Avise, 1994). Moreover, fish body morphometry and otolith chemistry have been commonly used for stock delineation, since variation in body morphometry and otolith chemistry between stocks indicates that different stocks have spent significant periods of their lives in different environments (Campana, 1999).

The first objective of the present study was to investigate the population structure of $S$. officinalis throughout the Marmara, Aegean and north-eastern Mediterranean Seas using PCR-RFLP analysis of mitochondrial ND 5/6 genes, morphometry and cuttlebone chemistry. The second objective was to determine the discriminative potential of cuttlebone chemistry for identifying populations. This study is the first to use cuttlebone chemistry to identify cuttlefish populations.

\section{MATERIALS AND METHODS}

\section{Sampling}

Samples were collected separately by commercial fishing vessels (Trawl) from four fishing ports in the Aegean (Izmir Bay), Marmara (Bandirma Bay) and north-eastern Mediterranean Seas (Antalya and Iskenderun Bays) (Fig. 1). Abbreviations of sampling areas are given in Table 1. Following capture, the cuttlefish specimens were immediately transferred to the laboratory. The sample size and relevant information of collected samples are given

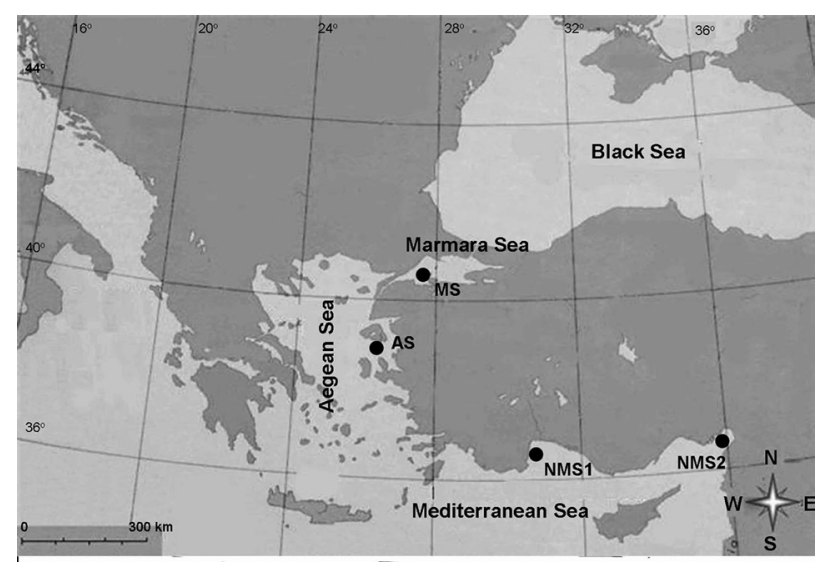

FIG. 1. - Map of the sampling locations for the common cuttlefish. - indicates sampling location; MS, Marmara Sea; AS, Aegean Sea; NMS1, north-eastern Mediterranean Sea (Antalya Bay); NMS2, north-eastern Mediterranean Sea (Iskenderun Bay). 
TABLE 1. - Sampling details of S. officinalis used in this study. MTL, mean total length (mm). Standard deviations of MTL are given in brackets. F, female; M, male.

\begin{tabular}{|c|c|c|c|c|c|c|}
\hline Sampling Area & Abbreviation & Sampling Area Coordinates & $\operatorname{Sex}(\mathrm{F} / \mathrm{M})$ & Sample size & MTL & Collection date \\
\hline Marmara Sea & MS & $400^{\circ} 36^{\prime} 02^{\prime \prime} \mathrm{N} 270^{\circ} 21^{\prime} 41^{\prime \prime} \mathrm{E}$ & $18 / 12$ & 30 & $35.32(4.19)$ & 17.01.2007 \\
\hline Aegean Sea & AS & $380^{\circ} 49^{\prime} 24^{\prime \prime} \mathrm{N} 260^{\circ} 33^{\prime} 27^{\prime \prime} \mathrm{E}$ & $17 / 13$ & 30 & $18.84(3.99)$ & 08.12 .2006 \\
\hline Mediterranean Sea (Antalya Bay) & NMS1 & $360^{\circ} 48^{\prime} 45^{\prime \prime} \mathrm{N} 300^{\circ} 41^{\prime} 11^{\prime \prime} \mathrm{E}$ & $24 / 6$ & 30 & $18.62(4.68)$ & 05.12 .2006 \\
\hline Mediterranean Sea (Iskenderun Bay) & NMS2 & $360^{\circ} 34^{\prime} 29^{\prime \prime} \mathrm{N} 350^{\circ} 50^{\prime} 08^{\prime \prime} \mathrm{E}$ & $17 / 13$ & 30 & $22.15(3.24)$ & 12.12 .2006 \\
\hline
\end{tabular}

in Table 1. In the laboratory, morphometric measurements $(\mathrm{mm})$ of the cuttlefish were taken of each specimen according to Kassahn et al. (2003). After the morphometric measurements had been taken, each individual was dissected: the cuttlebone was removed from the tissues and stored at $-30^{\circ} \mathrm{C}$.

\section{Genetic sampling}

Total DNA was extracted from the muscle using the standard phenol: chloroform: isoamyl alcohol procedure (Sambrook et al., 1989). PCR amplification of the mitochondrial ND 5/6 gene was carried out using the universal primers:

\section{ND5/6-a:5'-AACAGTTCATCCGTTGGTCTTAGG-3' ND5/6-b:5'-TAACAACGGTGGTTCTTCAAGTCA-3'}

The amplification was performed with a profile of $94^{\circ} \mathrm{C}$ for $4 \mathrm{~min}$, followed by 35 cycles of $94^{\circ} \mathrm{C} / 30 \mathrm{~s}$ strand denaturation, $52^{\circ} \mathrm{C} / 20 \mathrm{~s}$ annealing and $72^{\circ} \mathrm{C} / 1$ min $30 \mathrm{sec}$ primer extensions, and a final $7 \mathrm{~min}$ elongation at $72^{\circ} \mathrm{C}$. The ND 5/6 rDNA amplification conditions were: $1.5 \mu \mathrm{l} 10 \mathrm{x}$ polymerase buffer, 0.5 $\mu l$ dNTP $(10 \mathrm{mM}), 0.3 \mu \mathrm{l}$ Taq DNA polymerase (3 $\mathrm{U} / \mu \mathrm{l}), 0.10 \mu \mathrm{l}$ primers, $1 \mu \mathrm{l}$ template DNA, and water for a total reaction volume of $25 \mu \mathrm{l}$.

The PCR product was restricted with 6 endonucleases: BsurI (HaeIII), AluI, Bsh1236I (FnuDII), Hin6I (HhaI), RsaI, XhoI. The fragments of the restricted DNA samples were separated on 6\% polyacrylamide gels, together with a pGem marker (Promega). A modified silver nitrate staining protocol (Tegelstrom, 1987) was used to visualize the DNA fragments.

Nucleotide sequence diversities and divergence (Nei and Tajima, 1981) were determined using the REAP computer package (McElroy et al., 1991). The significance of geographic heterogeneity in haplotype distribution was tested using a Monte Carlo simulation (Roff and Bentzen, 1989) with 100 randomizations of the data. A molecular analysis of variance (AMOVA) using $\mathrm{F}_{\mathrm{ST}}$ was also performed to detect the level of gene flow between populations with Arlequin $v 3$ (Excoffier and Schneider, 2005). A mismatch analysis was performed using Arlequin $v 3$ to compare the occurrence of demographic changes in the populations (Rogers and Harpending, 1992). This analysis compares the distribution of the frequency of pairs of individuals who differ by a certain number of nucleotide differences. The distance matrices of pairwise comparisons among haplotypes were used to generate trees with the unweighted pair-group method with arithmetic averages (UPGMA; Sneath and Sokal, 1973) using PHYLIP $v 4$. Bootstrapping with replicates encompassing 1000 datasets was performed to investigate the robustness of nodes in each cluster.

PCR-RFLP generated fragment profiles were classified by letters which were then combined to define composite mtDNA haplotype patterns. The size of the restriction fragments were estimated from their mobilities relative to a standard DNA ladder molecular size marker using DNA-FRAG version 3.03 .

\section{Morphometric measurements}

Morphometric characters on the dorsal view and tentacular club of $S$. officinalis were measured with a digital compass. The abbreviations and name of the morphometric measurements are: TL total length; ML mantle length; MW mantle width: NW neck width; ED eye diameter; CSD club sucker diameter; CL club length; DBE distance between eyes (Fig. 2).

Significant linear correlations between all morphometric characters and the standard length of cuttlefish were detected. In order to eliminate any size effects in the dataset, an allometric formula by Elliott et al. (1995) and Lleonart et al. (2000) was applied to remove length effects in the samples. The efficiency of size adjustment was evaluated by testing the significance of correlations between transformed variables and the length of cuttlefish. All calculations were performed in SPSS and SYSTAT software packages. 
a)

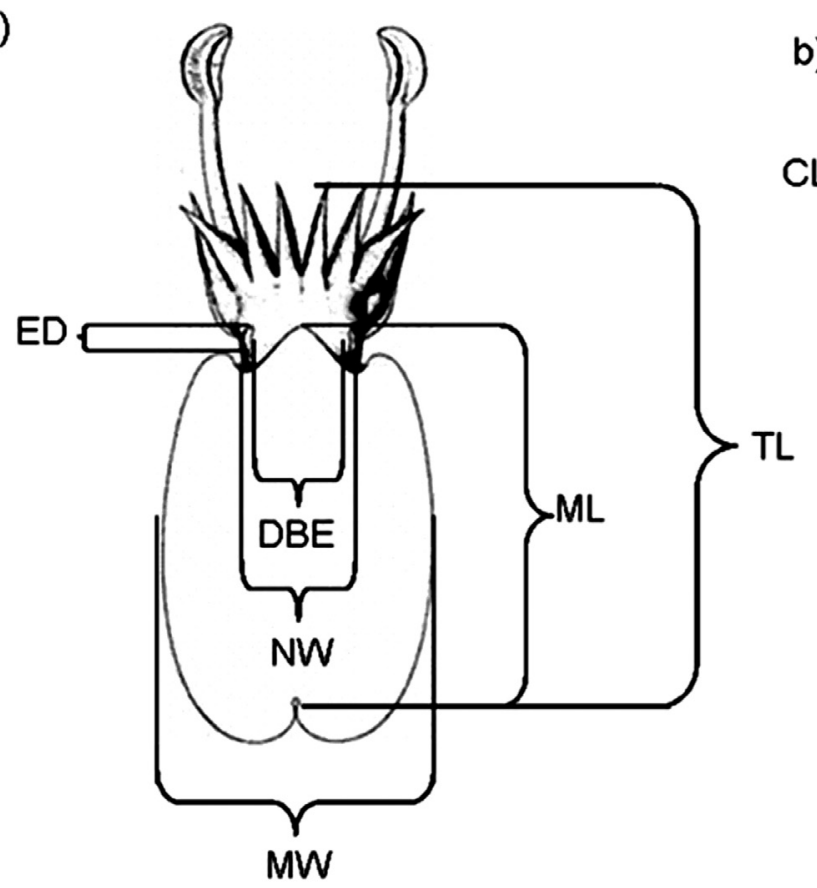

b)

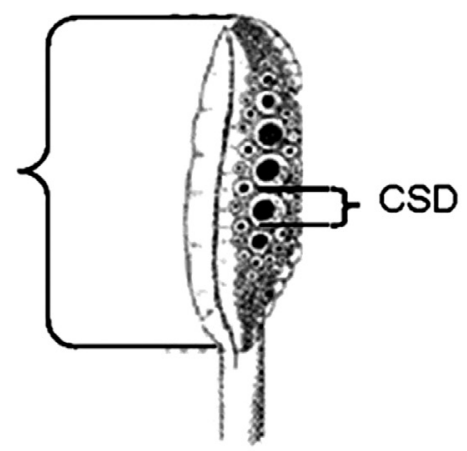

FIG. 2. - Morphometric characters of S. officinalis measured: a) dorsal view, b) tentacular club, TL total lenght; ML mantle length; MW mantle width: NW neck width; ED eye diameter; CSD club sucker diameter; CL club length; DBE distance between eyes.

\section{Cuttlebone chemistry}

The cuttlebones from all samples were dried at $65^{\circ} \mathrm{C}$ for 5 days to constant weight and then reduced to powder using a porcelain mortar and pestle. Aliquots $(500 \mathrm{mg})$ of the samples were digested with $4 \mathrm{ml}$ of $14 \mathrm{~N}$ Ultra pure $\mathrm{HNO}_{3}$ and $1 \mathrm{ml}$ of $22 \mathrm{~N}$ Ultra pure $\mathrm{HClO}_{4}$ at $100^{\circ} \mathrm{C}$ on a hot plate for 3 days. After evaporation of the acids, the residues were resuspended in $5 \mathrm{ml} 0.3 \mathrm{~N}$ HNO3. The blank was prepared in the same way as the samples. Concentrations of $\mathrm{Al}, \mathrm{Ca}$, $\mathrm{Cd}, \mathrm{Cr}, \mathrm{Cu}, \mathrm{Fe}, \mathrm{K}, \mathrm{Mg}, \mathrm{Mn}, \mathrm{Na}, \mathrm{Pb}, \mathrm{Zn}$ were analyzed by solution-based inductively coupled plasmaatomic emission spectrometry (ICP-AES; Varian ${ }^{\circledR}$ Liberty Series II, USA). A phosphor (P) standard was prepared from the Merck® Standards for ICPAES. The calibration curve was obtained with at least 5 to 7 points. The values of the elements and blank, obtained from the ICP-AES, were calculated and values expressed as $\mu$ g.g- 1 dry weight.

\section{RESULTS}

\section{Genetic results}

A total of 7 composite haplotypes was found from 120 individuals. The composite haplotypes and their occurrence in each population are given in Table 2. No haplotype sharing was observed among populations. The average haplotype and nucleotide diversity within populations were 0.1075 and 0.000818 respectively. The average nucleotide diversity and nucleotide divergence between samples were 0.010208 and 0.009390 respectively. The highest nucleotide divergence (0.015279) was observed between the Iskenderun Bay (NMS2) and Marmara Sea (MS) samples, and the lowest nucleotide divergence (0.003786) was observed between the Aegean Sea (AS) and Antalya Bay (NMS1) samples.

Tests for genetic heterogeneity in haplotype frequencies revealed overall highly significant heterogeneity $(P<0.001)$ among $S$. officinalis samples, which indicates genetic sub-structuring within the species (Table 3). In pairwise comparisons using Monte Carlo $\chi^{2}$ tests significant differences $(P<0.001)$ in haplotype frequency were observed between all samples (Table 3). Mantel's test showed that the genetic distances between the samples were significantly associated with their geographical association $(r=0.78 ; P<0.05)$. The AMOVA test also supported the highly restricted intermingling between the locations, especially between the Iskenderun Bay (NMS2) and Aegean Sea (AS) samples (Table 3). The parameters of the model of sudden expansion and the goodness-of-fit test to the 
TABLE 2. - Frequency of 7 composite mtDNA haplotypes from RFLP data within the studied stocks of $S$. officinalis. Letters reflect individual haplotypes for six restriction enzymes; BsurI, AluI, Bsh1236I, Hin6I, RsaI, XhoI (left to right). H, haplotype diversity; $N$, nucleotide diversity; S.E., standard error.

\begin{tabular}{|c|c|c|c|c|c|c|c|c|c|c|c|c|}
\hline \multirow[b]{2}{*}{ Haplotypes } & \multirow[b]{2}{*}{ BsurI } & \multicolumn{3}{|c|}{ Restriction enzymes } & \multirow[b]{2}{*}{ RsaI } & \multirow[b]{2}{*}{ Xhol } & & \multicolumn{5}{|c|}{ Sampling sites } \\
\hline & & AluI & Bsh1236I & Hin6I & & & & NMS1 & NMS2 & $\mathrm{AS}$ & MS & Total \\
\hline Type 1 & A & A & B & A & B & A & & 0 & 30 & 0 & 0 & 30 \\
\hline Type 2 & A & B & A & A & A & A & & 28 & 0 & 0 & 0 & 28 \\
\hline Type 3 & A & B & $\mathrm{C}$ & B & B & A & & 2 & 0 & 0 & 0 & 2 \\
\hline Type 4 & A & A & A & A & A & A & & 0 & 0 & 30 & 0 & 30 \\
\hline Type 5 & B & A & A & A & $\mathrm{C}$ & A & & 0 & 0 & 0 & 25 & 25 \\
\hline Type 6 & B & A & A & A & A & A & & 0 & 0 & 0 & 3 & 3 \\
\hline \multirow[t]{5}{*}{ Type 7} & B & B & B & A & $\mathrm{C}$ & A & & 0 & 0 & 0 & 2 & 2 \\
\hline & & & & & & & Total & 30 & 30 & 30 & 30 & 120 \\
\hline & & & $H$ & & & & & 0.1287 & 0.0000 & 0.0000 & 0.3011 & $\begin{array}{l}\text { Average } \\
0.1075\end{array}$ \\
\hline & & & S.E. $(+/-)$ & & & & & 0.07916 & 0.0000 & 0.0000 & 0.10222 & 0.00509 \\
\hline & & & $N$ & & & & & 0.001835 & 0.0000 & 0.0000 & 0.001437 & 0.000818 \\
\hline
\end{tabular}

TABlE 3. - Pairwise estimates of nucleotide divergence (below diagonal) and $\mathrm{F}_{\mathrm{ST}}$ (above diagonal) values among $S$. officinalis populations. $* * *$, significance value $(P<0.001)$.

\begin{tabular}{lcccc}
\hline Stock & NMS1 & NMS2 & AS & MS \\
\hline NMS1 & - & $0.92476 * * *$ & $1.00000^{* * *}$ & $0.96323 * * *$ \\
NMS2 & $0.013443 * * *$ & - & $0.83908 * * *$ & $0.88231 * * *$ \\
AS & $0.004704 * * *$ & $0.008774 * * *$ & - & $0.92687 * * *$ \\
MS & $0.011728^{* * *}$ & $0.015998^{* * *}$ & $0.006599 * * *$ & \\
\hline
\end{tabular}

TABLE 4. - Parameters of the sudden expansion model and goodness-of-fit test to the model with respective significance for each population. $S$, number of polymorphic sites; $\theta_{0}$, preexpansion population size; $\theta_{1}$, postexpansion population size; $\tau$, time in number of generations; SSD, sum of squared deviations; Hri; Harpening's Raggedness index; * Significant at $P<0.05$.

\begin{tabular}{lcccc}
\hline & \multicolumn{4}{c}{ Population } \\
Parameters & NMS1 & NMS2 & AS & MS \\
\hline $\mathrm{S}$ & 12 & 0 & 0 & 6 \\
$\theta_{0}$ & 0 & 0 & 0 & 0 \\
$\theta_{1}$ & 0.077 & 0 & 0 & 0.334 \\
$\tau$ & 3 & 0 & 0 & 3 \\
Hri & 0.79225 & 0 & 0 & 0.57465 \\
Goodness-of-fit test & & & & \\
SSD & $0.02428^{*}$ & 0 & 0 & 0.06640 \\
\hline
\end{tabular}

model in the mismatch analyses are given in Table 4. All populations were fitted to an expansion model. Estimated $\tau$ values (time in number of generations after expansion) were 0.077 and 0.334 for NMS1 and MS respectively. Zero $\tau$ values were detected for the other populations, indicating that population expansion in NMS2 and AS may be due to a recent bottleneck.

The genetic relationship between samples is summarized in the form of a UPGM dendrogram (Fig. $3)$. In the first clad, the Antalya Bay (NMS1) and Aegean Sea samples clustered as the closest clades,

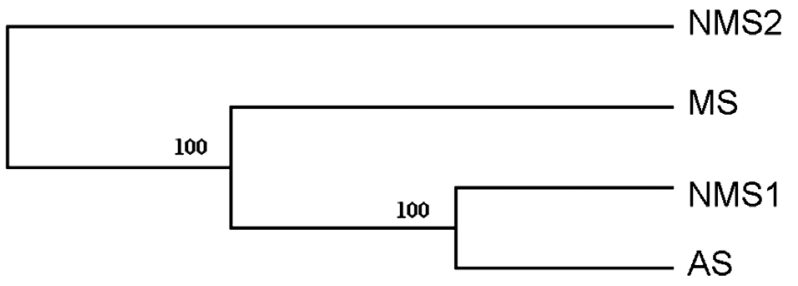

FIG. 3. - UPGMA phenogram of genetic relationships among populations of $S$. officinalis. Bootstrap estimates (as a percentage) are indicated above branches. MS, Marmara Sea; AS, Aegean Sea; NMS1, north-eastern Mediterranean Sea (Antalya Bay); NMS2, north-eastern Mediterranean Sea (Iskenderun Bay).

while the Marmara Sea sample was in the neighbouring clad. The Iskenderun Bay sample (NMS2) clustered as the most divergent (Fig. 3). High bootstrapping values were detected for each node on the UPGM dendrogram.

\section{Morphometric results}

Univariate statistics (ANOVA) revealed highly significant $(P<0.001)$ differences among locations for all 6 morphometric measurements. In DFA, the first DF accounted for $72 \%$ and the second accounted for $26 \%$ of the between-population variability. The graphic representation of the first two canonical axes revealed a clear separation of the Marmara Sea and Iskenderun Bay samples and overlapping of the Aegean Sea and Antalya Bay samples (Fig. 4). Mantel's tests using the Euclidean distance for morphometric characters $(r=0.59 ; P>0.05)$ between these samples were not significantly associated with geographical distances.

The overall percentage of reclassification by cross-validation was $66 \%$. The proportion of correctly classified individuals into their original sample 


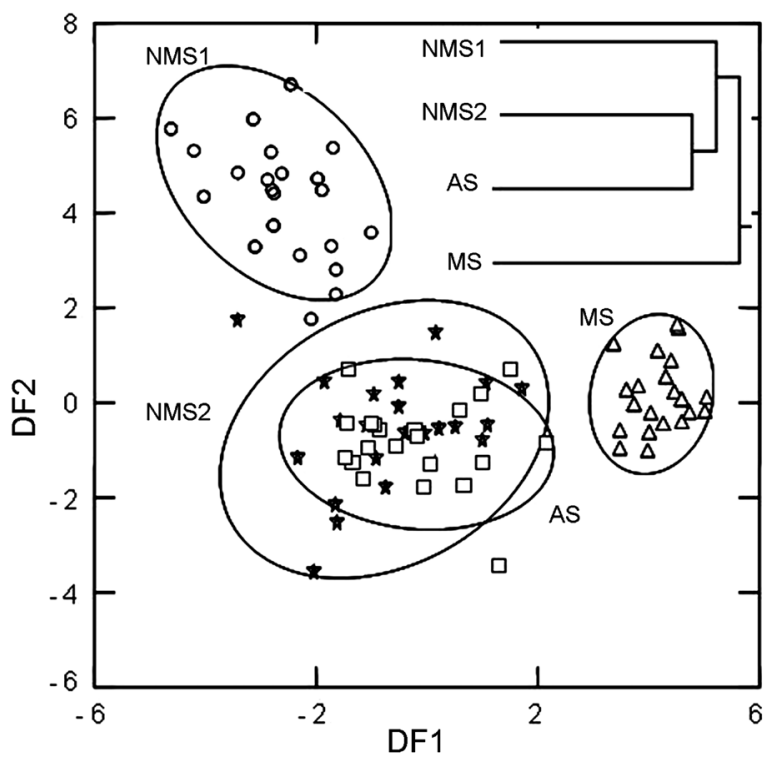

FIG. 4. - Confidence ellipses of DFA scores for morphometric analysis and UPGMA dendrogram based on Euclidean distance. MS, Marmara Sea; AS, Aegean Sea; NMS1, north-eastern Mediterranean Sea (Antalya Bay); NMS2, north-eastern Mediterranean Sea (Iskenderun Bay).

TABLE 5. - Euclidean distance between stocks of S. officinalis for morphometrics (below diagonal) and cuttlebone chemistry (above diagonal). Numbers in the diagonal (bold) are the percentage of individuals classified correctly into their original stock by morphometric / cuttlebone chemistry respectively.

\begin{tabular}{lcccc}
\hline Stock & NMS1 & NMS2 & AS & MS \\
\hline NMS1 & $\mathbf{4 3 / 1 0 0}$ & 17.847 & 112.372 & 46.211 \\
NMS2 & 83.531 & $\mathbf{7 8 / 1 0 0}$ & 124.925 & 56.341 \\
AS & 15.827 & 18.239 & $\mathbf{5 0 / 1 0 0}$ & 102.348 \\
MS & 22.499 & 24.199 & 19.561 & $\mathbf{9 3 / 1 0 0}$ \\
\hline
\end{tabular}

was high for the Marmara Sea (93\%) and Iskenderun Bay (78\%) samples (Table 5). The most important characters for distinguishing the MS sample were CSD, DBE and MW (Fig. 4 and 5). The most important characters in distinguishing the NMS1 sample were ED and CL.

\section{Cuttlebone chemistry}

Univariate statistics (ANOVA) revealed highly significant differences $(P<0.001)$ among samples for the 12 elements. The first and second discriminant functions contributed $72 \%$ and $26 \%$ to the total variance respectively, showing that the majority of total variance was explained by the first two canonical variables. Plotting all samples on the first two discriminant functions shows that all samples are very separate (Fig. 6). The overall assignment

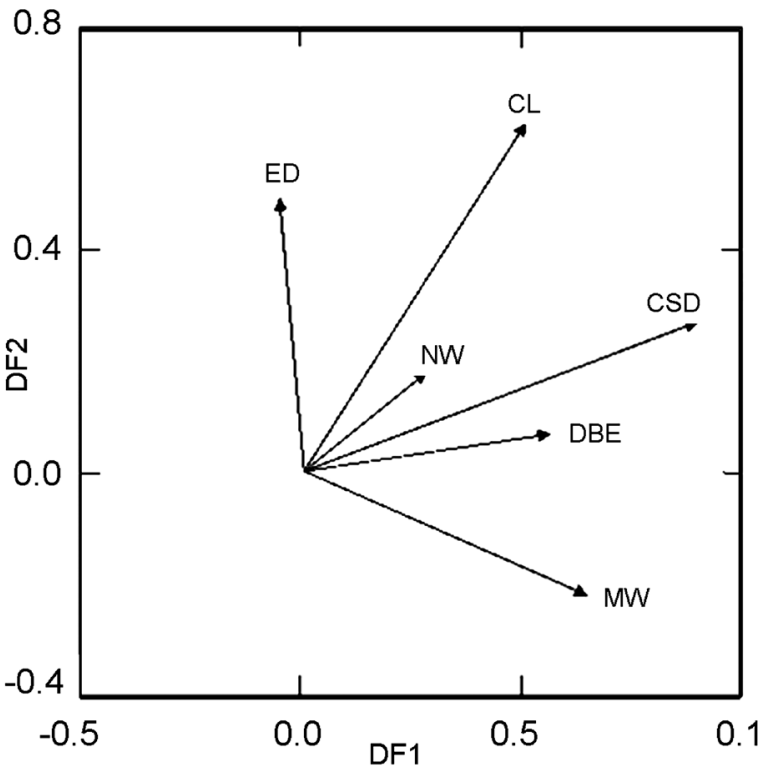

FIG. 5. - Contribution of morphometric characters to the discriminant functions. Vectors indicate the loadings of the scores for each variable on the first two discriminant functions. MW, mantle width; NW, neck width; ED, eye diameter; CSD, club sucker diameter; CL, club length; DBE, distance between eyes.

of individuals into their original sample was $100 \%$ (Table 5).

Examination of the contribution of each variable to the first canonical functions showed a high contribution from $\mathrm{Cu}$, which differentiated the Aegean Sea samples (Figs. 6 and 7). $\mathrm{Cr}$ and $\mathrm{Ca}$ contributed to the second canonical function and separated the Mar-

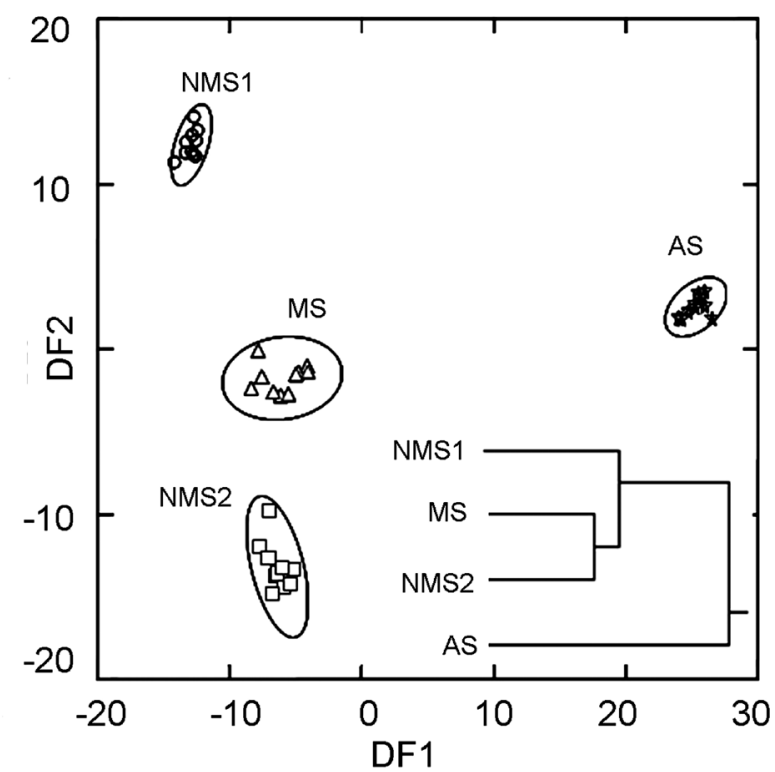

FIG. 6. - 95\% confidence ellipses of DFA scores for cuttlebone chemistry and UPGMA dendrogram based on Euclidean distance. MS, Marmara Sea; AS, Aegean Sea; NMS1, northeastern Mediterranean Sea (Antalya Bay); NMS2, north-eastern Mediterranean Sea (Iskenderun Bay). 


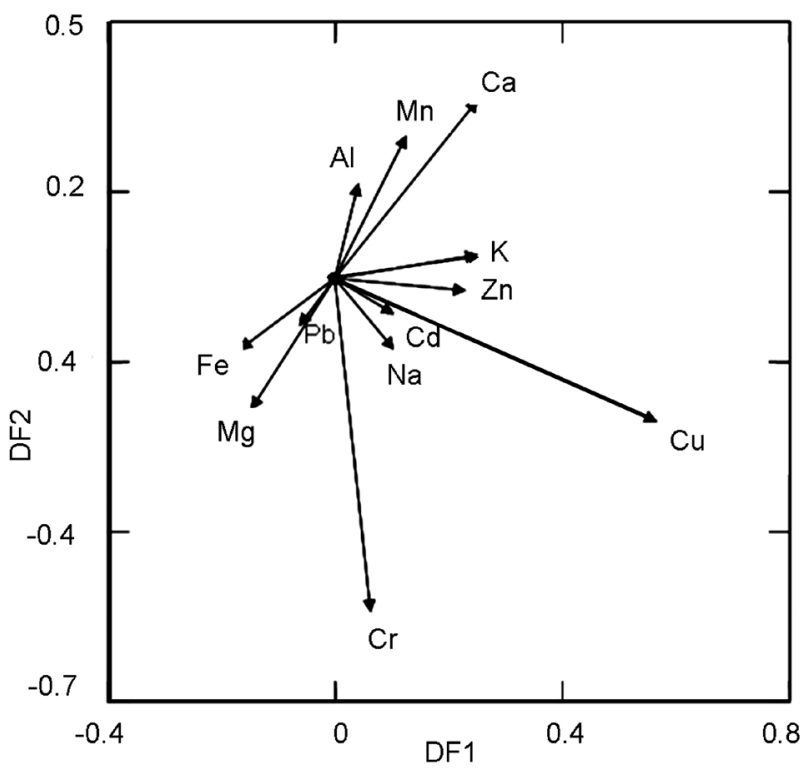

FIG. 7. - Contribution of cuttlebone chemistry elements to the discriminant functions. Vectors indicate the loadings of the scores for each variable on the first two discriminant functions.

mara and north-eastern Mediterranean Sea (NMS1 and NMS2) samples (Figs. 6 and 7). Mantel's test revealed that the Euclidean distance for cuttlebone chemistry between these populations was not significantly associated with geographical distances $(r=-0.30 ; P>0.05)$.

\section{DISCUSSION}

Genetic, morphologic and cuttlebone chemistry data from this study showed that there are discrete populations of $S$. officinalis in Turkish coastal waters. However, no haplotypes were shared among the four populations of $S$. officinalis, and genetic variation was not randomly distributed. Analysis of cuttlebone chemistry also showed many differences among the four geographic populations of S. officinalis, which is consistent with the genetic data. Morphometric data revealed three populations of $S$. officinalis along the Turkish coast. Only the neighbouring populations (NMS1 and AS) showed morphological similarity, which is not in agreement with the genetic and cuttlebone chemistry data already discussed.

Marine species generally show little genetic differentiation due to lack of major geographical barriers to dispersal and gene flow (Ward et al., 1994). Genetic divergence between populations of S. officinalis was found to be considerably high in compari- son to other marine species, which may be related to the limited dispersal ability of $S$. officinalis. Although females fix their eggs to the sea floor, there is no pelagic larval phase (benthic juveniles hatch directly from the eggs), and the adults have limited migratory capacities (Guerra, 1992). All population pairs separated by distances showed significant differences in haplotype frequencies, which indicates limited genetic exchange among areas. Nevertheless, the possibility of these geographically based genetic patterns resulting from adaptive responses to different environmental pressures (natural selection) or due to isolation by distance among populations cannot presently be excluded. There is evidence of selection acting on mtDNA genes (Ballard and Kreitman, 1995), and thus haplotype diversity may not always result from a stable neutral distribution. However, Mantel tests indicate a significant correlation between geographic and genetic distances, which suggests that the data fit to an isolation-by-distance model of gene flow. Therefore, the degree of geographic isolation in S. officinalis around the Turkish terrestrial waters is consistent with the degree of genetic differentiation. Similarly, Perez-Losada et al. (1999) studied genetic variation with microsatellite loci from NE Atlantic and Mediterranean coasts of the Iberian Peninsula and found highly significant subpopulation structuring, consistent with an isolation-by-distance model of gene flow. Wolfram et al. (2006) analyzed microsatellite DNA variation among $S$. officinalis populations in the English Channel and the Bay of Biscay, and reported that the genetic distance between the populations increases with geographic isolation.

Since mtDNA is a maternally inherited molecule there may be a differential population structure between sexes. The ratio of sexes was between 55 and $60 \%$ for females within MS, AS and NMS2 populations. A large percentage of the individuals analyzed in the NMS1 population were females (80\%) (Table 1). The possibility of a differential population structure between sexes is not valid since all populations have male individuals in moderate numbers.

Analyses of minor chemical constituents in fish otoliths have been successfully used to distinguish specific population differences for stock discrimination (Campana et al., 1994; Turan, 2006); however, to our knowledge, there is no study using cuttlebone chemistry for population identification of cuttlefish. The most important result of this study is the use cuttlebone chemistry to successfully identify cut- 
tlefish populations in agreement with genetic data. The method described here allowed $100 \%$ correct identification of cuttlefish specimens into their original sample based on 12 elements. Examination of the contribution of cuttlebone chemistry characters to discriminant functions demonstrates that $\mathrm{Cu}$ strongly contributes to the first discriminant function (Fig. 7) and plays a major role in discriminating the north-eastern Mediterranean and Marmara Sea populations from the Aegean Sea population (Fig. 6). Yazkan et al. (2004) analyzed the chemical contents of some molluscs in Antalya Bay and reported that cuttlefish contain the highest levels of $\mathrm{Cu}$ compared to the other molluscs. $\mathrm{Cr}$ and $\mathrm{Ca}$ play a role in discriminating two Mediterranean populations (Antalya Bay and Iskenderun Bay). Turan (2006) reported that the highest level of $\mathrm{Ca}$ in the otolith chemistry of Trachurus mediterraneus populations from Turkish waters is found in the Iskenderun Bay population. Therefore, the chemical compositions of local waters which are fed with different river systems may determine the cuttlebone chemistry of cuttlefish populations if there is restricted migration between locations.

The correlation between geographic distance and Euclidean distance of both cuttlebone chemistry and morphometrics of $S$. officinalis was not significant. However, morphometric data show more geographically concordant relationships than cuttlebone chemistry among the populations, since only the most geographically isolated populations (MS and NMS2) could be separated by DFA. The assessment of the contribution of each morphometric character to discriminant functions shows that differentiation among populations is association with the club sucker diameter, club length and eye diameter parts of the body, which may reflect adaptations to different habitat characteristics in each sea, such as water flow, depth and turbidity. For example, differences in club sucker diameter and club length may be attributed to water flow. In higher water flows, bigger clubs and club suckers are adapted to hang on rocks. The Marmara Sea has a higher water flow than Iskenderun Bay (Ozsoy et al., 1996), and the mean ratios of the club length and club sucker diameter characters to total length were bigger in the Marmara population ( 0.34 and 0.21 respectively) than the Iskenderun Bay population (0.29 and 0.19 respectively). Moreover, differences in eye diameter may be attributed to turbidity (Moore, 1950). The Marmara Sea has less turbid water than Iskenderun
Bay (Besiktepe et al., 1993). In more turbid waters eye diameter is expected to be small (Moore, 1950). The mean ratios of eye diameter to total length were larger in the Marmara population (0.50) than the Iskenderun Bay population (0.53). The detected morphological differences between populations of cuttlefish seem to be differential to the environmental factors. The use of morphologic characters to identify populations must take into account that these traits are a result of genetics and environmental influences. Lombarte and Lleonart (1993) reported that overall otolith shape is regulated genetically, and otolith size is influenced by environmental conditions. When two populations are clearly different in morphological terms, it can be inferred that they may have genetic differences, may have been during their lifetime subject to consistently different environmental influences, or a mixture of both. The detected morphologic differences are supported by genetic and cuttlebone chemistry data which indicate the adaptation of stocks to different environments with phenotypic and genetic characters.

The number of unique haplotypes and their spatial distribution are useful for assessing the genetic structure and gene flow among populations (Hauser et al., 2001). The pattern of haplotype frequency differences observed among all populations appeared to be related to geographic distances. Therefore, the detection of unique haplotypes and the spatial distribution of each population may be indicative of the adaptation of the population in each biotope and the lack of migration across long distances.

The detected mean haplotype (0.1075) and nucleotide (0.000818) diversity of $S$. officinalis are very low. The Aegean and Iskenderun Bay populations in particular showed zero diversity. The relationship between haplotype and nucleotide diversity provides information on population demographic history. Low haplotype and nucleotide diversity are interpreted as recent bottlenecks or a founder event (Grant and Bowen, 1998). Cuttlefish have a short life span of around 2 years. Given the short life span, large inter-annual fluctuations in landings, and the regular annual migration cycle, it is expected that marine environment conditions have an important impact on cuttlefish recruitment and distribution (Boletzky, 1983). Cephalopod fisheries are expanding on the Turkish coasts, and fish stocks are becoming over exploited. Moreover, pollution in the Izmir and Iskenderun Bays due to the industrialization of these two areas is also a major reason for the de- 
cline in marine stocks (Salman and Katağan, 2004). Therefore, the detected low haplotype and nucleotide diversity may be related to a recent bottleneck due to the above mentioned environmental pressures, which is supported by the mismatch analysis.

In comparison with microsatellite and allozyme data with previous studies (Perez-Losada et al., 1999, Shaw et al., 1999; Perez-Losada et al., 2002), mitochondrial DNA restriction fragment length polymorphism can detect structuring as given by microsatellite analysis (Shaw et al., 1999; Perez-Losada et al., 2002). However, higher levels of polymorphism were shown in the microsatellite analysis than in the RFLP. Allozyme is a weak estimator of genetic diversity and divergence as reported by Perez-Losada et al. (1999) in comparison with RFLP and microsatellite analysis.

Cuttlebone chemistry is a good estimator of population differentiation, although detected cuttlebone chemistry differences between populations were supported by genetic data. Furthermore, cuttlebone chemistry has greater potential than morphometrics for stock identification. It identifies populations on a small geographical scale, which indicates the greater capacity of cuttlebone chemistry versus morphometrics to detect fine stock structuring.

In conclusion, due to the observed high genetic, cuttlebone chemistry and morphometric discreteness, the Marmara, Aegean and two north-eastern Mediterranean (Antalya Bay and Iskenderun Bay) populations may be considered four self-recruited populations. The detected significant levels of genetic, cuttlebone chemistry and morphometric differentiation among populations imply demographic differentiation, and demographically separated populations should be managed and conserved as separate units (Carvalho and Hauser, 1994). Whilst this information is relevant to management of the increasing commercial exploitation of this species, additional repeat sampling will be needed to establish if these findings are spatially present and temporally stable. Moreover, the use of nuclear genes with different genetic markers such as microsatellites in these populations would strengthen these findings.

\section{ACKNOWLEDGEMENTS}

Thanks are due to the Turkish Academy of Sciences in the framework of the young scientist award program (TUBA-GEBIP-2005), MKU BAP for financial support, and Dr. Kemal Sangun for help in the laboratory. The genetic part of this study was generated from the MSc thesis of DY.

\section{REFERENCES}

Avise, J.C. - 1994 Molecular Markers, Natural History and Evolution, Chapman and Hall, New York. 511pp.

Ballard, J.W.O. and M. Kreitman. - 1995. Is mitochondrial DNA a strictly neutral marker? Trends Ecol. Evol., 10: 485-488.

Besiktepe, S., E. Ozsoy and U. Unluata. - 1993. Filling of the Marmara Sea by the Dardanelles Lower Layer Inflow. Deep-Sea Res., 40: 1815-1838.

Boletzky, S.V. - 1983. Sepia officinalis, In: P.R. Boyle (ed.), Cephalopod Life Cycles: Species Accounts, Vol. I, pp. 31-52. Academic Press, London.

Campana, S.E. - 1999. Chemistry and composition of fish otoliths: pathways, mechanisms and applications. Mar. Ecol. Prog. Ser., 188: 263-297

Campana, S.E., A.J. Fowleii and C.M. Jones. - 1994. Otolith elemental fingerprinting for stock identification of Atlantic cod (Gadus morhua) using laser ablation ICPMS. Can. J. Fish. Aquat. Sci., 51: 1942-1950.

Carvalho, G.R. and L. Hauser. - 1994. Molecular-genetics and the stock concept in fisheries. Rev. Fish. Biol. Fish., 4: 326-350.

Duysak, Ö., C. Türeli and Ü. Erdem. - 2004. Fauna of Cephalopods in Akkuyu (Eastern Mediterranean-Mersin, Turkey). Turk. J. Aqu. Lif., 2: 181-192.

Elliott, S.R., P. Beiersdorfer, B.J. McGowan and J. Nilsen. - 1995. Measurements of line overlap for resonant spoiling of x-ray lasing transitions in nickellike tungsten. Physical Rev., 52: 2689-2692.

Excoffier, L.G. and L. Schneider, S. - 2005. Arlequin ver. 3.0: An integrated software package for population genetics data analysis. Evol. Bioinform. Online, 1: 47-50.

FAO. - 2003. Cephalopods commodity update. Available from http://www.globefish.org/publications/commodityupdate/ 200311/200311.htm.

Grant, W.S. and B.W. Bowen. - 1998. Shallow population histories in deep evolutionary lineages of marine fishes: insights from the sardines and anchovies and lessons for conservation. J. Hered., 89: 415-426.

Guerra, A. - 1992. Mollusca, Cephalopoda. In: M.A. Ramos et al. (eds.), Fauna Ibérica, Vol. 1. Museo Nacional de Ciencias Naturales (CSIC), Madrid.

Hauser, L., C. Turan and G.R. Carvalho. - 2001. Haplotype Frequency Distribution and Discriminatory Power of Two mtDNA Fragments in a Marine Pelagic Teleost (Atlantic herring, $\mathrm{Clu}$ pea harengus). Heredity, 87: 1-10.

Kassahn, K.S., S.C. Donnellan, A.J. Fowler, K.C. Hall, M. Adams and P.W. Shaw. - 2003. Molecular and morphological analyses of the cuttlefish Sepia apama indicate a complex population structure. Mar. Biol., 143: 947-962.

Lleonart, J., J. Salat, and G.J. Torres. - 2000. Removing allometric effects of body size and allometry in morphological analysis. $J$. Theor. Biol., 205: 85-93.

Lombarte, A. and J. Lleonart. - 1993. Otolith size changes with body growth, habitat depth and temperature. Environ. Biol. Fish., 37: 297-306.

McElroy, D., P. Moran, E. Bermingham and J. Kornfield. - 1991. Reap: The restriction enzyme analysis package, version 4.0. Department of Zoology, University of Maine, Orono, ME.

Moore, G.A. - 1950. The cutaneous sense organs of barbeled minnows adapted to life in the waters of the Great Plains region. Trans. Am. Microsc. Soc., 519: 69-95.

Nei, M. and F. Tajima. - 1981. DNA polymorphism detectable by restriction endonucleases. Genetics, 97: 145-163.

Ozsoy, E., M.A. Latif, H.I. Sur and Y. Goryachkin. - 1996. A Review of the Exchange Flow Regimes and Mixing in the Bosphorus Strait. In: F. Briand, (ed.), Mediterranean Tributary Seas, Bull. Inst. Océanogr., Monaco, Special Number 17, CIESM Sci. Ser., 2, Monaco. 
Perez-Losada, M., A. Guerra and A. Sanjuan. - 1999. Allozyme differentiation in the cuttlefish Sepia officinalis (Mollusca: Cephalopoda) from the NE Atlantic and Mediterranean. Heredity, 83: 280-289.

Perez-Losada, M., A. Guerra, G.R. Carvalho, A. Sanjuan and P.W. Shaw. - 2002. Extensive population subdivision of the cuttlefish Sepia officinalis (Mollusca: Cephalopoda) around the Iberian Peninsula indicated by microsatellite DNA variation. Heredity, 89: 417-424.

Perrin, A., E. LeBihan and N. Koueta. - 2004. Experimental study of enriched frozen diet on digestive enzymes and growth of juvenile cuttlefish Sepia officinalis L. (Mollusca Cephalopoda). J. Exp. Mar. Biol. Ecol., 311: 267-285.

Roff, D.A. and P. Bentzen. - 1989. The statistical analysis of mitochondrial DNA polymorphisms: 2 and the problem of small samples. Mol. Biol. Evol., 6: 539-545.

Rogers, A. R. and H. Harpending. - 1992. Population growth makes waves in the distribution of pairwise genetic differences. Mol. Biol. Evol. 9: 552-569.

Salman, A. and T. Katağan. - 2004. Türkiye Denizlerindeki Kafadanbacaklıların (Cephalopoda) Av Verimleri 1. Ulusal Malakoloji Kongresi 1-3 Eylül 2004 Izmir-Türkiye. Türk Sucul Yaşam Dergisi, 2(Suppl. 2): 25-32.

Salman, A., T. Katağan and H.A. Benli. - 1997. Bottom trawl teuthofauna of the Aegean Sea. Arch. Fish. Mar. Res., 45(Suppl. 2): $183-196$

Sambrook, J., E.F. Fritsch and T. Maniatis. - 1989. Molecular Cloning: a Laboratory Manual, 2nd edn. Cold Spring Harbor, NY: Cold Spring Harbor Laboratory.

Shaw, P.W., G.J. Pierce and P.R. Boyle - 1999. Subtle population structuring within a highly vagile marine invertebrate, the veined squid Loligo forbesi, demonstrated with microsatellite DNA markers. Mol. Ecol., 8: 407-417.

Sneath P.H.A. and R.R. Sokal - 1973. Numerical Taxonomy. W.H.
Freeman, San Francisco.

Tegelstrom, H. - 1987. Genetic variability in mitochondrial DNA in a regional population of the Great Tit (Pagrus major). Biochemical Genetics. 25: 95-110.

Turan, C., M. Oral., B. Öztürk and E. Düzgüneş. - 2006. Morphometric and Meristic Variation between stocks of Bluefish (Pomatomus saltatrix) in the Black, Marmara, Aegean and Northeastern Mediterranean Seas. Fish. Res., 79: 139-147.

Turan, C. -2006 . The use of otolith shape and chemistry to determine stock structure of Mediterranean horse mackerel Trachurus mediterraneus (Steindachner). J. Fish. Biol., (Suppl. C) 69: $165-180$.

Turan C., B.Ozturk, M. Gurlek and D. Yaglioglu. - 2009. Genetic differentiation of Mediterranean horse mackerel (Trachurus mediterraneus) populations as revealed by mtDNA PCR-RFLP analysis. J. Appl. Ichthyol., 25: 142-147.

Volpedo, A.V. and A.F. Cirelli. - 2006. Otolith chemical composition as a useful tool for sciaenid stock discrimination in the south-western Atlantic. Sci. Mar., 70(Suppl. 2): 325-334.

Ward, R.D., M. Woodwark and D.O.F. Skibinski - 1994. A comparison of genetic diversity levels in marine, freshwater, and anadromous fishes. J. Fish. Biol. 44: 213-232.

Wolfram, K., F.C. Mark, U. John, M. Lucassen and H.O. Portner. - 2006. Microsatellite DNA variation indicates low levels of genetic differentiation among cuttlefish (Sepia officinalis L.) populations in the English Channel and the Bay of Biscay. Comp. Biochem. Physiol. D., 1: 375-383.

Yazkan, M., F. Özdemir and M. Gölükcü. - 2004. Antalya Körfezinde Avlanan Bazı Yumuşakçalar ve Karideste $\mathrm{Cu}, \mathrm{Zn}, \mathrm{Pb}$ ve Cd içeriği. Turk. J. Vet. Anim. Sci., 28: 95-100.

Scient. ed.: P. Sánchez.

Received October 23, 2008. Accepted March 24, 2009.

Published online November 23, 2009. 